\title{
Pemberian Pakan Nabati Tumbuhan Air Yang Berbeda Terhadap Pertumbuhan dan Kelangsungan Hidup Benih Ikan Koan (Ctenopharyngodon idella)
}

\author{
${ }^{1}$ Robi Choirom , ${ }^{2}$ Syahrizal dan ${ }^{* 2}$ Safratilofa \\ ${ }^{1}$ Alumni Program Studi Budidaya Perairan Fakultas Pertanian, Universitas Batanghari \\ ${ }^{2}$ Program Studi Budidaya Perairan, Fakultas Pertanian Universitas Batanghari \\ Jl. Slamet Riyadi, Broni Jambi. 36122. Telp. +62074160103 \\ ${ }^{1)}$ Email korespondensi : choirom221@gmail.com
}

\begin{abstract}
Koan fish is very attractive to consumers because it has good taste, has white flesh, is very thick and chewy in all parts of its body. Feed is one of the important components in fish farming activities, namely 50\% - 70\% of production costs. The price of fish feed continues to increase and is not accompanied by an increase in the selling price of cultured fish. Therefore to increase the production of koan fish (C. idella), it is necessary to have a research experiment on the effect of different vegetable feeds on the growth and survival of koan fish (C. idella). Vegetable feeds given are Lemna minor, Azolla Microphylla, Pistia stratiotes, Eichornia crassipes. Before the feed is given to the seed feed it is mashed using a knife to become food that can be eaten by koan fish (C. idella) seeds. Feeding is done satiety given as much as 3 times a day (morning, afternoon and evening). Test seeds are koan fish that are 60 days old. Fish kept for 30 days. Intake of fish sample that will be measured length and body weight gain is done once every ten days ie on days 0, 10, 20 and finally on day 60. Based on the results and research the effect of different plant-based feeds of Water Plants gives a different effect significantly on the growth and survival of koan fish (C. idella), the best growth in absolute weight of koan fish (C. idella) is found in the treatment of catfish eye plants, which is 1.38 grams. The highest survival rate is in the treatment of giving catfish eye plants that is $36 \%$.
\end{abstract}

Keywords : Ctenopharyngodon idella, Lemna minor, Azolla Microphylla, Pistia stratiotes, Eichornia crassipes

\begin{abstract}
Abstrak. Ikan koan sangat diminati oleh konsumen karena memiliki rasa yang enak, memiliki daging berwarna putih, sangat tebal dan kenyal pada seluruh bagian tubuhnya. Pakan merupakan salah satu komponen penting dalam kegiatan budidaya ikan yaitu 50\% - 70\% dari biaya produksi. Harga pakan ikan yang terus meningkat dan tidak disertai kenaikan harga jual ikan hasil budidaya. Oleh karena itu untuk meningkatkan produksi budidaya ikan koan (C. idella) perlu adanya percobaan penelitian pengaruh pemberian pakan nabati yang berbeda terhadap pertumbuhan dan kelangsungan hidup benih ikan koan (C. idella). Pakan nabati yang diberikan yaitu Mata lele, Azolla Microphylla, Kayu Apu, Eceng Gondok. Sebelum pakan di berikan kepada benih pakan dihaluskan menggunakan pisau menjadi pakan yang dapat di makan oleh benih ikan koan (C. Idella). Pemberian pakan dilakukan secara kenyang yang diberikan sebanyak sebanyak 3 kali sehari (pagi,siang dan sore). Benih uji adalah ikan koan yang telah berumur 60 hari. Ikan dipelihara selama 30 hari. Pengambilan sempel ikan yang akan diukur pertambahan panjang dan bobot tubuhnya dilakukan setiap sepuluh hari sekali yaitu pada hari 0, 10, 20 dan yang terakhir pada hari ke - 60. Berdasarkan hasil dan penelitian pengaruh pemberian pakan nabati Tumbuhan Air yang berbeda memberikan pengaruh yang tidak berbeda nyata terhadap pertumbuhan dan kelangsungan hidup benih ikan koan $(C$. idella), Pertumbuhan bobot mutlak benih ikan koan $(C$. idella) yang terbaik terdapat pada perlakuan pemberian tumbuhan mata lele yaitu sebesar 1,38 gram. Tingkat kelangsungan hidup tertinggi terdapat pada perlakuan pemberian tumbuhan mata lele yaitu sebanyak $36 \%$.
\end{abstract}

Kata Kunci : Ctenopharyngodon idella, Lemna minor, Azolla Microphylla, Pistia stratiotes, Eichornia crassipes.

\section{PENDAHULUAN}

Ikan Koan (Ctenopharyngodon idella) dalah ikan introduksi yang berasal dari Cina yang di datangkan ke Indonesia pada tahun 1915 dengan tujuan untuk di budidayakan. Ikan ini merupakan salah satu jenis ikan ekonomis penting dalam budidaya perikanan air tawar karena ikan ini memiliki rasa yang enak dengan dagingnya yang berwarna putih, sangat kenyal dan tebal di seluruh bagian tubuhnya.

Upaya dalam memenuhi kebutuhan konsumsi masyarakat akan ikan koan yang semakin meningkat, sehingga membuat intensitas penagkapan ikan koan dari alam semakin tinggi. Untuk mengatasi hal tersebut sektor budidaya ikan koan menjadi solusinya terutama pada kegiatan pembesaran untuk ukuran konsumsi. Proses kegiatan pembesaran pada masa budidaya membutuhkan stok benih yang berkualitas dan memadai.

Pakan merupakan salah satu komponen penting dalam kegiatan budidaya ikan. Disatu sisi, pakan merupakan sumber materi dan energi untuk menopang kelangsungan hidup dan pertumbuhan ikan namun disisi lain pakan merupakan komponen terbesar $(50 \%-70 \%)$ dari biaya produksi. Harga pakan ikan yang terus meningkat dan tidak disertai kenaikan harga jual ikan hasil budidaya adalah permasalahan yang harus dihadapi setiap pembudidaya ikan. 
Robi Choirom, Syahrizal, dan Safratilofa. Kepadatan Optimum Ikan dan Tanaman Air Pada Pemeliharaan Ikan Patin (Pangasius hypophthalmus) dengan Sistem Akuaponik

Oleh karena itu, upaya pencarian pakan alternatif yakni pakan alami yang murah serta mudah dijangkau terus dilakukan agar dapat mengurangi biaya produksi.

\section{METODOLOGI PENELITIAN}

Penelitian ini dilaksanakan selama dua bulan pada bulan Januari sampai dengan bulan maret 2019. Tempat pelaksanaan penelitian di UPTD BBID Instalansi Telanaipura Provinsi Jambi, Adapun alat yang digunakan dalam pelaksanaan rancangan penelitian ini antara lain, akuarium benih, pompa air, selang ukuran $1 / 2$ inc, aerator, pipa paralon, serok halus mangkok, baskom literan air, timbangan digital, alat pengukur kualitas air, alat tulis, kamera digital, penggaris, sipon, botol sampel.

Ikan uji yang digunakan dalam penelitian ini adalah benih ikan koan sebanyak 144 ekor. Benih ikan koan didapat dari hasil pemijahan secara semi buatan di BBI Telanaipura. Benih ikan koan yang akan digunakan untuk penelitian ini adalah benih yang telah berumur 2 bulan dengan ukuran panjang benih rata-rata $5,86 \mathrm{~cm}$

Wadah yang digunakan adalah akuarium dengan ukuran $(50 \times 30 \times 30 \mathrm{~cm})$ sebanyak 12 unit. Sebelum digunakan akuarium terlebih dahulu di bersihkan menggunakan air bersih kemudian dikeringkan atau dijemur dibawah sinar matahari selama kurang lebih 2 hari dengan tujuan menetralisir sisa-sisa kotoran yang menempel didalam akuarium. Akuarium yang sudah dikeringkan kemudian disusun dan diberikan label sesuai undian pada masing-masing perlakuan, setelah dilabel akuarium diisi air dengan jumlah volume air sebanyak 22,5 liter. Air yang digunakan dalam penelitian ini berasal dari air sumur yang telah diendapkan selama kurang lebih 3 hari, diberikanaerasi untuk memperkaya kandungan oksigen di dalam air media pemeliharaan benih ikan koan.

Pakan yang akan di berikan selama pemeliharaan berupa pakan nabati yaitu Mata lele, Azolla Microphylla, Kayu Apu, Eceng Gondok. Sebelum Pakan yang di berikan kepada benih sebaiknya pakan tersebut di Proses menjadi pakan yang dapat di makan oleh benih ikan koan (C. Idella) dan timbang terlebih dahulu, Pemberian pakan dilakukan secara kenyang (satiasi), frekuensi pemberian pakan sebanyak 3 kali yaitu pada pagi, siang, dan sore hari. Kandungan nutrisi yang terdapat di dalam pakan masing masing akan dilakukan proksimat terdiri dari kadar abu, protein, lemak, serat.

\section{Parameteryang Diamati \\ Pertumbuhan Bobot Mutlak}

$\mathbf{P b m}=\mathbf{W}_{\mathbf{t}}-\mathbf{W}_{\mathbf{o}}$

Keterangan :

$\mathrm{Pbm} \quad$ : Pertumbuhan bobot mutlak (gr)

$\mathrm{W}_{\mathrm{t}} \quad$ : Bobot rata-rata pada akhir penelitian (gr)

$\mathrm{W}_{\mathrm{o}} \quad$ : Bobot rata-rata pada awal penelitian (gr)

\section{Pertumbuhan Panjang Mutlak}

Pertumbuhan Panjang Mutlak (PL) dihitung berdasarkan rumus Effendie (1997) dalam (Diatin et al. 2014):

\section{$\mathbf{P L}=\mathbf{L t}-\mathbf{L O}$}

Keterangan :

Lt = panjang rata-rata ikan pada waktu $\mathrm{t}(\mathrm{cm})$

L0 = panjang rata-rata ikan pada awal percobaan $(\mathrm{cm})$

\section{Tingkat Kelangsungan Hidup}

Kelangsungan hidup (SR) adalah tingkat perbandingan jumlah ikan yang hidup dari awal hingga akhir penelitian. Kelangsungan hidup dapat dihitung dengan rumus (Muchlisin et al., 2016) .

$S R=\frac{(\mathrm{No}-\mathrm{Nt})}{\mathrm{No}} \times 100 \%$

Keterangan:

$\mathrm{SR}=$ Kelangsungan hidup (\%),

$\mathrm{Nt}=$ Jumlah ikan di akhir penelitian (ekor)

No $=$ Jumlah ikan awal penelitian (ekor) 
Robi Choirom, Syahrizal, dan Safratilofa. Kepadatan Optimum Ikan dan Tanaman Air Pada Pemeliharaan Ikan Patin (Pangasius hypophthalmus) dengan Sistem Akuaponik

\section{Pertumbuhan Bobot Mutlak}

\section{HASIL DAN PEMBAHASAN}

Berdasarkan hasil pengamatan dan analisis sidik ragam terhadap pertumbuhan bobot mutlak benih ikan koan (C.idella) yang diberi perlakuan berupa pemberian jenis pakan nabati tanaman darat yang berbeda disajikan pada Tabel 1.

Tabel 1. Rerata pertumbuhan bobot mutlak benih ikan koan (C.idella) yang diberi perlakuan berupa pemberian jenis pakan nabati tanaman air yang berbeda

\begin{tabular}{lccccc}
\hline \multicolumn{1}{c}{ PERLAKUAN } & \multicolumn{3}{c}{ Ulangan } & TOTAL & RATA-RATA \\
A (Azolla Microphylla) & 1,16 & 2 & 3 & 3,25 & $1,08^{\mathrm{a}}$ \\
B (Eceng gondok) & 0,89 & 0,46 & 1,63 & 2,13 & $0,71^{\mathrm{a}}$ \\
C (Kiyapu) & 0,28 & 0,59 & 0,59 & 1,57 & $0,52^{\mathrm{a}}$ \\
D (Mata Lele) & 1,13 & 1,33 & 1,67 & 4,13 & $1,38^{\mathrm{a}}$ \\
Total & & & & 11,08 & 3,69 \\
Rata-Rata & & & 2,77 & 0,92 \\
\hline
\end{tabular}

Berdasarkan hasil uji lanjut menunjukkan bahwa perbedaan pemberian jenis pakan nabati tanaman Air memberikan pengaruh yang berbeda tidak nyata terhadap pertumbuhan bobot benih ikan koan (C.idella). Data pada Tabel 1 menunjukkan bahwa pertumbuhan bobot mutlak tertinggi terdapat pada perlakuan D yaitu sebesar (1,38 gram) selanjutnya diikuti oleh perlakuan A (1,08 gram), kemudian perlakuan B (0,71 gram) dan perlakuan C (0,52 gram).

Tingginya pertumbuhan bobot mutlak pada perlakuan $\mathrm{D}$ (mata lele) dan perlakuan $\mathrm{A}$ (A. microphylla) dikarenakan kandungan proteinnya.Menurut Hasil Uji Proksimat(Lampiran 4) kandungan protein mata lele sebesar $37,71 \%$ dan kandungan protein azolla microphylla $28,15 \%$. Ikan yang diberi pakan dengan kandungan protein yang tinggi maka pertumbuhannya akan cepat bertambah. Menurut Ilyas(2014) kandungan protein mata lele sangatlah tinggi sehingga sewaktu ikan memakan makanan tersebut maka pertumbuhan ikan akan cepat bertambah sehingga sangatlah baik diberikan sebagai pakan benih ikan. Berbeda dengan pertumbuhan bobot mutlak benih $\operatorname{koan}(C$. idella $)$ pada perlakuan $\mathrm{B}$ dan $\mathrm{C}$ yang cenderung lebih rendah. Hal ini diduga terjadi karena kandungan serat yang terdapat pada tumbuhan tersebut tinggi sehingga menyebabkan ikan susah mencerna makanan tersebut.

Menurut Sahwan (2003) dalam Samuel Lante (2015) Protein berfungsi sebagai zat pembangun dan membentuk jaringan baru untuk pertumbuhan, pergantian jaringan yang rusak, hormone, pengatur berbagai proses metabolisme dalam tubuh, serta sebagai sumber energi pada saat kebutuhan energi tidak terpenuhi oleh karbohidrat dan lemak.

Menurut Noegroho (2000) protein memegang peranan penting dalam penyusunan jaringan dan organ tubuh ikan. Dalam pakan yang diberikan kepada ikan, protein harus tersedia dalam jumlah yang cukup. Protein yang rendah akan mengakibatkan pertumbuhan ikan akan menjadi lambat. Kisaran kebutuhan protein dalam pakan ikan untuk ikan di daerah tripis, kadar protein antara $20-60 \%$.

\section{Tingkat Kelangsungan Hidup}

Berdasarkan hasil pengamatan dan analisis terhadap tingkat kelangsungan hidup ikan koan(C. idella) yang diberi perlakuan berupa perbedaan pemberian jenis pakan nabati tanaman air di sajikan pada Gambar 2 .

\section{TKH}

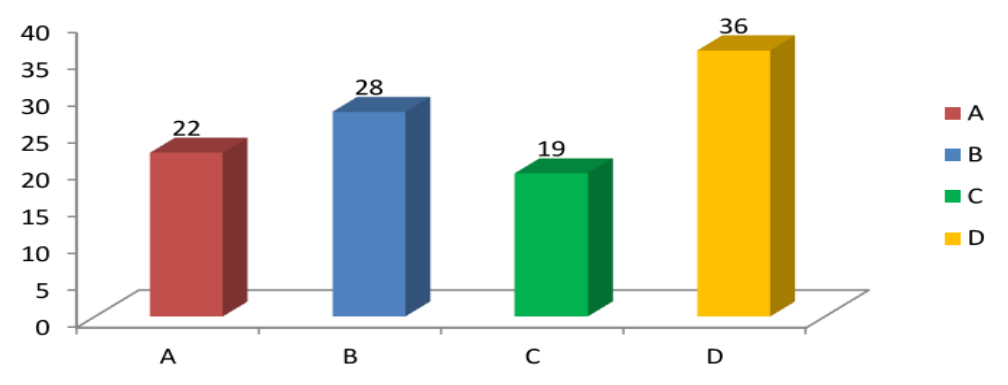

Gambar 1. Rerata kelangsungan hidup ikan koan (C.idella) Pemberian pakan nabati perlakuan A(Azolla Microphylla) B(Ecenggondok) C(Kayu apu) D(Mata Lele) 
Berdasarkan hasil analisis sidik ragam pada taraf 5\% menunjukkan bahwa perbedaan pemberian jenis pakan nabati tanaman air memberikan pengaruh yang berbeda tidak nyata terhadap kelangsungan hidup ikan koan (C.idella). Namun demikian data pada Gambar 7 menunjukkan bahwa Tingkat kelangsungan hidup tertinggi terdapat pada perlakuan D yaitu sebesar (36), selanjutnya diikuti oleh perlakuan B (28), kemudian perlakuan A (22) dan perlakuan C (19).

Rendahnya Tingkat Kelangsungan Hidup benih ikan koan diduga karena tingginya amonia pada kualitas air perlakuan C (19) dapat menyebabkan kematian pada ikan (Effendi, 2003). Menurut Patra et al, (2009) dalam yanuartono (2017). Saponin merupakan senyawa dalam bentuk glikosida yang tersebar luas pada tanaman tingkat tinggi serta beberapa hewan laut dan merupakan kelompok senyawa yang beragam dalam struktur, sifat fisika kimia dan efek biologisnya. Pada awalnya para ahli nutrisi secara umum sependapat bahwa saponin merupakan senyawa yang dapat mengganggu pertumbuhan dan kesehatan Khalil et al (1994). Dan di duga penyebab kematian pada benih ikan koan (C.idella) dikarenakan adanya kandungan saponin.

\section{Kualitas Air}

Selama berlangsungnya penelitian dilakukan pengambilan sampel air uji dan selanjutnya dianalisa di Laboratorium. Hasil analisa terhadap beberapa parameter kualitas air disajikan pada Tabel 3

Tabel 2. Rerata kualitas air pertumbuhan dan kelangsungan hidup benih ikan koan ( C. Idella)

HASIL UJI

\begin{tabular}{cccccccccccc}
\hline NO & Parameter & Satuan & Awal & \multicolumn{2}{c}{ A } & \multicolumn{2}{c}{ B } & \multicolumn{2}{c}{ C } \\
\hline & & & $011-1$ & $011 ; 2$ & $011-3$ & $011-2$ & $011-3$ & $011-2$ & $011-3$ & $011-2$ & $011-3$ \\
1 & Suhu & ${ }^{\circ} \mathrm{C}$ & 29 & 29 & 29,1 & 28,9 & 28,9 & 29 & 28,9 & 29 & 29 \\
2 & $\mathrm{pH}$ & - & 6,8 & 5,7 & 5,3 & 5,5 & 5,2 & 5,6 & 5,4 & 5,7 & 5,4 \\
3 & $\mathrm{DO}$ & $\mathrm{mg} / \mathrm{L}$ & 6,7 & 5,0 & 5,2 & 5,3 & 5,3 & 5,4 & 5,3 & 5,3 & 5,3 \\
4 & $\mathrm{CO}^{2}$ & $\mathrm{mg} / \mathrm{L}$ & 2,0 & 2,4 & 2,7 & 2,4 & 2,8 & 2,3 & 2,5 & 2,2 & 2,7 \\
5 & Amonia & $\mathrm{mg} / \mathrm{L}$ & 0,001 & 0,007 & 0,012 & 0,008 & 0,013 & 0,007 & 0,010 & 0,006 & 0,012 \\
\hline
\end{tabular}

Sumber : : Hasil Analisis di lab. Universitas Batanghari

Keterangan: 011-1 : Air Awal Penelitian

011-2 : Air Tengah Penelitian ( 30 Hari )

011-3 : Air Akhir Penelitian ( 60 Hari )

Berdasarkan hasil analisis laboratorium terhadap parameter kualitas air menunjukkan bahwa parameter kualitas air yang diuji yaitu suhu, $\mathrm{pH}$, DO dan $\mathrm{CO}_{2}$ tergolong baik untuk pemeliharaan benih ikan koan (C.idella). Kisaran parameter kualitas air untuk ikan koan (C.idella) adalah kadar oksigen $>5 \mathrm{ppm}$, temperatur $25-32^{\circ} \mathrm{C}, \mathrm{CO}_{2} 2-$ 6 ppm dan $\mathrm{pH}$ 6,5-7,0. Namun untuk parameter $\mathrm{NH}_{3}$ menunjukkan nilai yang cukup bervariasi, yaitu $0,0001 \mathrm{mg} / \mathrm{L}$ pada tengah penelitian meningkat hingga $0,0007 \mathrm{mg} / \mathrm{L}$ pada akhir penelitian perlakuan $\mathrm{A}$, meningkat hingga 0,0009 $\mathrm{mg} / \mathrm{L}$ pada pertengahan penelitian meningkat hingga $0,0008 \mathrm{mg} / \mathrm{L}$ pada akhir penelitian perlakuan $\mathrm{B}$,meningkat hingga $0,010 \mathrm{mg} / \mathrm{L}$ pada pertengahan penelitian meningkat hingga 0,0007 pada akhir penelitian perlakuan $\mathrm{C}$ meningkat hingga $0,010 \mathrm{mg} / \mathrm{L}$ pada pertengahan penelitian meningkat hingga $0,006 \mathrm{mg} / \mathrm{L}$ pada akhir penelitian perlakuan $\mathrm{D}$ meningkat hingga $0,012 \mathrm{mg} / \mathrm{L}$.

\section{KESIMPULAN}

Berdasarkan hasil dan penelitian pengaruh pemberian pakan nabati Tumbuhan Air yang berbeda. memberikan pengaruh yang tidak berbeda nyata terhadap pertumbuhan dan kelangsungan hidup benih ikan koan $(C$. idella), Pertumbuhan bobot mutlak benih ikan koan $(C$. idella) yang terbaik terdapat pada perlakuan pemberian tumbuhan mata lele yaitu sebesar 1,38 gram. Tingkat kelangsungan hidup tertinggi terdapat pada perlakuan pemberian tumbuhan mata lele yaitu sebanyak $36 \%$

\section{DAFTAR PUSTAKA}

Affandi, R., Sjafei, D.S., Raharjo, M.F., Sulistiono. 1992. Fisiologi ikan (Pencernaan). Pusat Antar Universitas llmu Hayat. Institut Pertanian Bogor. Bogor.

Aras. A. K., Nirmala.K., Soelistyowati.D.K., Sudarto. 2016. Manipulasi spektrum cahaya terhadap pertumbuhan dan kualitas warna yuwana ikan botia Chromobotia macracanthus (Bleeker, 1852). Jurnal Iktiologi Indonesia, Volume 16 Nomor 1, Februari 2016. 16(1):45-55 
Robi Choirom, Syahrizal, dan Safratilofa. Kepadatan Optimum Ikan dan Tanaman Air Pada Pemeliharaan Ikan Patin (Pangasius hypophthalmus) dengan Sistem Akuaponik

Asis,A., M. Sugihartono., M. Ghofur. 2017. Pertumbuhan Ikan Patin Siam (Pangasianodon hypopthalmus F.)Pada Pemeliharaan Sistem Akuaponik dengan kepadatan yang berbeda.Jurnal Akuakultur Sungai dan Danau. Vol. 2 No. 2 Tahun 2017 Hal. 51 - 57ISSN Print 2503-4766 ISSN Online 2597-8837

Babo.D.,Sampekalo.J.,Pangkey.H.,Pengaruh beberapa jenis pakan hijauan terhadap pertumbuhan ikan Koan Ctenopharyngodon idella

Damayanti. 2003. Pengaruh Salinitas Air terhadap kelangsungan Hidup dan Pertumbuhan benih Ikan Gurame (Osphronemus goramy Lac). Skripsi. FPIK. Bogor.

Diatin.I., Haris.E., Suprayudi.M.A., Budiardi.T. 2014. Pertumbuhan dan kelangsungan hidup ikan hias koridoras(Corydoras aeneus Gill 1858) pada budi daya kepadatan tinggi. Jurnal iktiologi indonesiaVolume 14 Nomor 2, Juni 2014. 14(2):123-134

Diler, Z. A., Tekinay, Güroy dan Soyutürk. 2007. Effects of Pistia stratiotes on the Growth Feed Intake and Body Composition of Common carp Cyprinus carpio L. Journal of Biological Sciences, 7 (2): 305-308

Effendi, 2000, Telaah Kualitas Air bagi Pengelolaan Sumberdaya Lingkungan Perairan, Jurusan Manajemen Sumberdaya Perairan, Fakultas Perikanan dan Ilmu Kelautan, IPB, Bogor.

Effendie. 1997. Biologi Perikanan. Yayasan Pustaka Nusatara: Yogyakarta. 163 hal.

Ernawan. D., 2010. Pengaruh Penggenangan Dan Konsentrasi Timbal (Pb) Terhadap Pertumbuhan Dan Serapan Pb Azolla microphylla Pada Tanah Berkarakter Kimia Berbeda

Handajani, H. 2011. Optimalisasi Substitusi Tepung Azolla Terfermentasi Pada Pakan Ikan untuk Meniingkatkan Produktivitas Ikan Nila Gift. Jurnal Teknik Industri Vol. 12 (2): 177-18p.

Hasyim. N., 2016. Potensi FtoremediasiEceng gondok (Eichornia crassipes) Dalam Mereduksi Logam Berat Seng (Zn) Dari Perairann Danau Tempe Kabupaten Wajo. Skripsi.

Ilyas, A. P., K. Nirmala, E. Harris, dan T. Widiyanto. 2014. Pemanfaatan Lemna perpusilla Sebagai Pakan Kombinasi Untuk Ikan Nila (Oreochromis niloticus) Pada Sistem Resirkulasi. Jurnal Limnotek, 21: (2): 193-201..

Iqbal, S. 1999. Duckweed aquaculture potentials: Possibilities and limitations for combined wastewater treatment and animal feed production in developing countries. EAWAG, SANDEC Report No. 6/99.

Iskandar, R dan Elrifadah. 2015. Pertumbuhan dan efisiensi pakan ikan nila (Oreochromis niloticus) yang diberi pakan buatan berbasis kiambang. Fakultas Pertanian Universitas Achmad Yani, banjarbaru. Jurnal ZIRAA'AH vol. 40 No. 1.Hal : 18-24 ISSN ELEKTRONIK 2355-3545

Landesman, L, N. C. Parker, C. B. Fedler, and M. Konikof. (2005). Modeling duckweed growth in wastewater treatment systems. Livestock Research for Rural Development. 17 (6) 2005.

Lumpkin,T. A. et al D. L. Plucknett. 1982. Azolla as green manure: Use and Management in Crop Production. Coloraddo: West View Press Inc. Skripsi.

Mahardi, 2009. Potensi Azolla (Azolla Pinnata) Sebagai Pakan Berbasis Lokal.

Muchlisin, Z.A., A.A. Arisa, A.A. Muhammadar, N. Fadli, I.I. Arisa, M.N. Siti Azizah. 2016. Growth performance and feed utilization of keureling (Tor tambra) fingerlings fed a formulated diet with different doses of vitamin E (alpha-tocopherol). Archives of Polish Fisheries, 24: 47-52.

Nursyakia. Laporan Akhir: Studi pemanfaatan eceng gondok Sebagai bahan pembuatan pupuk kompos Dengan menggunakan aktivator em4 dan Mol Serta prospek pengembangannya. UNHAS Makassar, 2014.

Putranti,G,P. Subandiyono, Pinandoyo. Journal of Aquaculture Management aand technology Volume 4, Nomor 3, Tahun 2015, Halaman $38-45$.

Resmikasari, Y. 2008. Tingkat Kemampuan Ikan Koan (Ctenopharyngodon idella) Memakan Gulma Air Eceng Gondok (Eichhornia crassipes (Mart) Solms.). Departemen Manajemen Sumberdaya Perairan. Fakultas Perikanan dan Ilmu Kelautan. Institut Pertanian Bogor. 74 hal. Skripsi.

Rizal.M.,2012. Pengaruh Tinggi Air Media Kultur Terhadap Pertumbuhan Dan Biomassa. Skripsi

Saanin. H. 1968. Taksonomi dan Kunci Identifikasi Ikan, Jilid I, Binatjipta, Bandung, 256.

Safitri. 2009. Analisis Risiko Produksi Daun Potong di PT Pesona Daun Mas Asri Bogor [skripsi. Bogor : Fakultas Ekonomi dan manajemen, Institut Pertanian Bogor.

Setiawan.F., 2013.Budidaya Ikan Koan di Kolam Terpal.Book.Hal.5.

Steel, R.G.D. dan J.H. Torrie. 1993. Prinsip dan Prosedur Statistika Suatu Pendekatan Biometrik. Penerbit PT. Gramedia Pustaka Utama, Jakarta.

Sucipto dan Prihartono (2007), Pembesaran Nila Hitam Bangkok di Karamba Jaring Apung, Kolam Air Deras, Kolam Air Tenang dan Karamba. Penerbit Penebar Swadaya, Jakarta.

Yanto, H. 2012. Kinerja MS-222 dan Kepadatan Ikan Botia (Botia macracanthus) yang Berbeda Selama Transportasi. Fakultas Perikanan dan Ilmu Kelauta. Universitas Muhammadiyah Pontianak. Pontianak 1 (1) : 43-51.

Yanuartono. Dampak Saponin terhadap Ternak (2017) 6(2) : 80 - 90. 
Robi Choirom, Syahrizal, dan Safratilofa. Kepadatan Optimum Ikan dan Tanaman Air Pada Pemeliharaan Ikan Patin (Pangasius hypophthalmus) dengan Sistem Akuaponik

Yudhitstira, S. 2013. Pengaruh Penggunaan Daun Apu-apu (Pistia stratiotes) Hasil Fermentasi Aspergillus niger dalam Pakan Buatan Terhadap Pertumbuhan Benih Ikan Nilem (Osteochilus hasselti). Skripsi FPIK. UNPAD. 57 hlm. (Tidak diterbitkan) 